\title{
NOTE
}

\section{THE LIABILITY OF NATURAL GAS PIPELINE COIVPANIES FOR BREACH OF CONTRACT DUE TO FPC-ORDERED CURTAILMENT}

Within the past several years the United States has begun to experience a diminishing supply of natural gas. ${ }^{1}$ As early as 1970 , not only were proven reserves already largely committed to sales to established customers and thus unavailable to new customers, ${ }^{2}$ but gas pipeline companies ${ }^{3}$ were finding themselves unable to meet even their existing contract demands. ${ }^{4}$ As a result of this shortage, numerous gas pipeline companies sought the assistance of the Federal Power Commission (FPC) ${ }^{5}$ in implementing plans to curtail gas deliveries to customers that employed the gas for "inferior" uses. ${ }^{6}$ Because of

1. See FPC v. Louisiana Power \& Light Co., 406 U.S. 621, 626 n.2 (1972); Placid Oil Co. v. FPC, Civil No. 71-2761 (5th Cir. Apr. 16, 1973); Southern La. Area Rate Cases v. FPC, 428 F.2d 407, 437-39 (5th Cir. 1970). See generally FPC, Stafr Report No. 2, National Gas Supply aNd Demand 1971-1990 (1972); FPC, STAFF REPORT ON NaTional Gas SUPPLy AND DEMAND (1969).

HEREINAFTER THE FOLLOWING CITATIONS WILL BE USED IN THIS NOTE:

A. Corbin, Contracts (1963) [hereinafter cited as CoRBIN];

RESTATEMENT OF CONTRACTS (1932) [hereinafter cited as RESTATEMENT];

S. Williston, Treatise on the LAW of Contracts (rev. ed. 1938) [hereinafter cited as WinlISTON].

2. See FPC, STafF REPoRT No. 2, supra note 1. Proven reserves, gas known to be available for sale from currently existing gas wells, have dropped $10 \%$ in the contiguous 48 states from 1967 to 1970.

3. The national natural gas industry is traditionally divided into three major components: (1) natural gas producers, (2) transmission or pipeline companies, and (3) distribution companies or utilities. This Note will deal primarily with the current shortage as it relates to the pipeline companies.

4. See Placid Oil Co. v. FPC, Civil No. 71-2761, at 24 n.14 (5th Cir. 1973); FPC STAFF REPORT No. 2, supra note 1, at xi.

5. The FPC regulates the gas industry pursuant to the Natural Gas Act, 15 U.S.C. $\S \$ 717$ et seq. (1970).

6. In particular, United Gas Pipe Line Co., expecting its supply of gas to be short by $20 \%$, proposed a gas dehvery curtailment plan. Pursuant to section 5 (d) of the Administrative Procedure Act (APA), which authorizes an agency to "issue a declaratory order to determine a controversy or remove uncertainty," 5 U.S.C. $\$ 554$ (e) (1970), United sought a declaratory order from the FPC that this plan was consistent with its obligation under its FPC gas tariff. See United Gas Pipe Line Co., No. 71-120 (F.P.C. Op. No. 606, Oct. 5, 1971). 
the extent of the shortage, the FPC found that reacting to the problein on a case-by-case basis through approval of irregularly submitted individual curtailment plans and authorization of short term einergency purchases ${ }^{7}$ was not adequate to solve the problem. As a result the FPC issued Order $431 .^{8}$ This order stated that every pipeline company under the FPC's jurisdiction should thereafter take all necessary steps to assure an adequate gas supply to their then existing customers for the forthcoming 1971-72 heating season. It also required each counpany to file a written report with the FPC to describe the means by which it proposed to comply with this order, including any curtailment plans it deemed to be necessary. ${ }^{9}$

A number of pipeline companies subsequently curtailed existing orders from customers in order to comply with Order 431 . This resulted in actions against the pipelines by the curtailed customers for breach of contract, the final outcomes of which are as yet unresolved. ${ }^{10}$ The decision whether the pipelines will be held liable for breaching their contracts in order to comply with the FPC order will have an enormous impact on the gas industry, the public, and the FPC's regulatory capacity. This resolution will determine whether the premiums paid by customers to obtain substitute fuels will be imposed upon the pipelines themselves or directly on the pipelines' customers. Equally significant, the resolution will directly affect the FPC's ability efficiently to assure adequate service under conditions of gas shortage.

Recent statements by the FPC and the courts of appeals suggest conflicting views as to whether gas pipelime companies should be liable for breach of contract to their customers when, in the face of a gas shortage, they curtail deliveries in ways approved or ordered by the FPC. In United Gas Pipe Line Co., ${ }^{11}$ the Commission indicated that

For a discussion of the FPC's statutory authority for curtailment, see notes 30-37 infra and accompanying text. The FPC's jurisdiction over curtailment of direct sales was upheld by the Supreme Court in FPC v. Louisiana Power \& Light Co., 406 U.S. 621 (1972).

7. FPC Order Nos. 402, 35 Fed. Reg. 7511 (1970), and 402-A, 35 Fcd. Reg. 8927 (1970), authorize short-term purchases from other pipelines in shortage situations. FPC Order No. 418, 35 Fed. Reg. 19,173 (1970), authorizes similar purchases from producers.

8. 18 C.F.R. \& 2.70 (1972).

9. Id.

10. See Atlanta Gas Light Co. v. Southern Natural Gas Co., 338 F. Supp. 1039 (N.D. Ga. 1972), aff'd in part, vacated and remanded in part, 476 F.2d 142 (5th Cir. 1973); Monsanto Co. v. FPC, 463 F.2d 799 (D.C. Cir. 1972).

11. No. 71-120 (F.P.C. Op. No. 606, Oct. 5, 1971). United Gas held that the Commission had jurisdiction to order implementation of United's curtailment of direct 
curtailment pursuant to Order 431 would be an absolute defense to liability:

Implementation of the curtailment plan itself, pursuant to our procedures, would be an absolute defense for [the pipeline] against all claims for specific performance, damages, or other requests for relief under these contracts affected by curtailments which may be initiated in the courts. ${ }^{12}$

Accordingly, the FPC found unnecessary a provision in the contract which would have expressly insulated the pipelme from the obligation to pay customers for the excess cost of substitute fuels burned during curtailment, ${ }^{13}$ since curtailment by the FPC was held to be an absolute defense. Furthermore, the Commission declined to render a declaratory order which would limit the pipeline's liability under such clauses, on the grounds that such an order would likewise be unnecessary if implementation of an FPC curtailment plan itself were an absolute defense. ${ }^{14}$ Subsequently, however, in Monsanto Co. $v$. $F P C,^{15}$ a case in which a customer sued for damages and injunctive relief following a pipeline's curtailment, the Court of Appeals for the

customers. Various customers had objected to United's proposed curtailment plan largely on the grounds that the FPC lacked jurisdiction to curtail deliveries to industrial and commercial users under direct sales contracts. The customers relied on section 1(b) of the Natural Gas Act, 15 U.S.C. § 717(b) (1970), which placed restrictions on the FPC's jurisdiction over direct sales. The Commission found that its power to curtail must necessarily encompass direct sales contracts if the Commission is to deal effectively with gas shortages. Id. at 12 . It remanded to the hearing examiner for interpretation and implementation of United's proposed plan.

All but one party eventually approved a settlement for the 1970-71 winter season while the proceedings continued; however, all legal issues were reserved. Monsanto, a United custoner, refused to accept the settlement and filed suit against United in the United States District Court for the District of Columbia, seeking damages for breach of contract and injunctive relief. Monsanto declared its contract rights were impaired by United's curtailment program both prior and subsequent to the FPC's approval of the settlement. This case is now before the District Court for the District of Columbia, pending the conclusion of the administrative proceedings. See Monsanto Co. v. FPC, 463 F.2d 799 (D.C. Cir. 1972).

12. United Gas Pipe Line Co., No. 71-120 (F.P.C. Op. No. 606, Oct. 5, 1971) (emphasis added).

13. See notes 93-101 infra and accompanying text for a discussion of privately agreed-upon contractual provisions, including substitute fuel clauses, and their effectiveness as a means of imposing liability on a pipeline for breach of contract due to curtailment.

14. No. 71-120 at 17 (F.P.C. Op. No. 606, Oct. 5, 1971). In United Gas Pipe Line Co., No. 71-120 (F.P.C. Op. No. 606-A, Dec. 3, 1971), in which a rehearing of No. 606 was denied, a dissenting Commissioner took issue with this strong language and referred to it as simply "self-serving dictum not binding on anyone, least of all the courts . ... No. 606-A, at 2 (dissenting opinion).

15. 463 F.2d 799 (D.C. Cir. 1972). 
District of Columbia indicated that FPC-ordered curtailment would not be an absolute defense, stating: "even assuming the FPC's curtailment jurisdiction is upheld, along the lines developed in its Opinion No. 606 , it does not automatically follow that plaintiffs are lacking a contract remedy in damages." the case that even if the FPC's action in rationing a limited supply of gas were proper the pipeline company could be liable if it had created the shortage. ${ }^{17}$

The court's statement in Monsanto concerning the pipeline company's liability, and the statement of the FPC in Opinion 606, are dicta since neither body finally resolved the question of liability in its decision. Thus, although the conflicting opinions do not definitely indicate the stances of the two bodies, they do suggest a conflict in views. While the court in Monsanto implied that it would hold a pipeline company hable if it were at fault in creating the shortage, the "absolute defense" language of the FPC in Opinion No. 606 suggests that, even where the pipeline company is at fault in creating the gas shortage, it cannot be held liable for a breach resulting from curtailment pursuant to FPC order. Language by the FPC implying protection from liability occurs in FPC opinions both before and after the Monsanto case. ${ }^{18}$ In a later curtailment opinion, however, the "absolute defense" language was modified to state that implementation of an FPC order would ouly "limit liability."

In light of the modification by the FPC of its absolute defense language, the seemingly divergent interpretations can perhaps be rec-

16. Id. at 808. In the prior district court proceedings, motions had been made to dismiss the action as a collateral attack on an FPC decision. The district court held that the matter was within the FPC's jurisdiction and dismissed the action. See id. at 801. The court of appeals remanded, holding that the district court should retain jurisdiction over the damage action pending a decision by the FPC as to whether it had jurisdiction of the case. Id. at 806-08.

17. Id. In an earlier case, the Court of Appeals for the Sixth Circuit implied that a pipeline would not be liable for breach of contract where it curtailed deliveries pursuant to an FPC curtailment order, so long as the pipeline complied with the order. Michigan Consol. Gas Co. v. Panhandle E. Pipe Line Co., 226 F.2d 60, 71 (6th Cir. 1955), cert. denied, 350 U.S. 987 (1956). For a discussion of the Panhandle litigation, see notes 85-89 infra and accompanying text.

18. United Gas Pipe Line Co., No. 71-120 (F.P.C. Oct. 5, 1971), was issued prior to Monsanto. Similar language appeared following Monsanto in Northern Natural Gas Co., No. 71-107, at 17 (F.P.C. Oct. 2, 1972). The Monsanto holding was felt to be contrary to the FPC's position when viewed on remand by the hearing examiner. United Gas Pipe Line Co., No. 71-120, at 24 n.1 (F.P.C., July 3, 1972) (presiding examiner's initial decision on remanded issues).

19. Northern Natural Gas Co., No. 71-107, at 17 (F.P.C., Oct. 2, 1972). The Commission further stated that "it is the act of implementing a Commission-approved curtailment plan that should serve to limit liability under outstanding contracts." Id. 
onciled by suggesting that the liability referred to by the court in Monsanto was only that which would arise in the event of fault in creating the gas shortage on the part of the pipeline or curtailment prior to FPC approval, and that the "absolute defense" referred to by the FPC assumes the absence of such complicating factors as fault on the part of the pipeline. Nevertheless, a determination of the exact circumstances under which a pipeline would be liable for curtailment pursuant to an FPC order requires further consideration of various factors which complicate such a simple theory of liability. ${ }^{20}$

This Note will first examine the effect of FPC gas regulation on private contracts to supply gas. Discussion will then center both on possible defenses to an action for breach of contract in the event a pipeline curtails deliveries in accordance with an FPC order, and on previous cases in which enforcement of customers' contract rights was sought in spite of FPC-approved curtailment. Consideration will then be given to the difficulty of ascertaining liability due to complex contract provisions, the propriety of the pipeline's initial allocation of its available gas, and the extent to which a pipeline can be at fault for creating a gas sliortage when it is subject to FPC regulation. Finally, certain policy considerations necessarily involved in the development of a theory of pipeline liability will be discussed.

\section{The Role of Private Contract in FPC Gas Regulation}

A determination of when an action for breacl of contract will lie where FPC regulation has hindered performance will depend in part upon the degree of control the FPC is held to have over private contracts. If private contracts are held to be subject to total control by the FPC, and the Commission elects to exercise that authority, it would seein patently unjust to hold a pipeline liable for compliance with an ordered change in contract terms.

The autonomy of private contract in the regulatory scheme has varied throughout the history of the FPC's regulation of natural gas, and the structure of regulation established by the Natural Gas Act

20. The realization by suppliers and purchasers of natural gas that the supply of natural gas is not limitless may cause the parties to take steps in the future to avoid ever having to obtain a court decision concerning the allocation of liability for losses incurred due to curtailment. Parties may begin to provide in their contracts for the distribution of this liability, dependent, of course, upon the willingness of the courts to enforce snch provisions. See notes 85-89, 95-101 infra and accompanying text. Nevertheless, the prospects for a continued shortage of gas point to the continued relevance of the issues involved as the courts outline the bounds of FPC-sanctioned freedoin of contract. In addition, it is perhaps unrealistic to expect that all parties have been or will be so prudent as to provide for the contingency of FPC curtailment. 
presently permits private contractual arrangements to be controlling in several areas. ${ }^{21}$ For example, in contrast to rate-making procedures followed by other regulatory agencies, ${ }^{22}$ section 4 of the $\mathrm{Act}^{23}$ permits the suppliers themselves initially to set gas rates. Recently, the Commission enacted an optional pricing procedure desigued to enhance the gas companies' rate-making powers and to encourage the exploration for new reserves and the commitment of these reserves to service. ${ }^{24}$ Similar individual initiative is allowed in determining whether a new source will be committed to service and whether old facilities will be abandoned. ${ }^{25}$

The Act also specifies certain cases in which private contracts may be abrogated in the public interest. Section 4 of the Act provides for the filing of new contractual provisions with the Commission for review and possible modification to prevent "unreasonable difference" anong customers in "rates, charges, services, facilities or in any other aspect." 28 Section 5 gives the FPC authority to investigate whether any new or old rate, charge, or classification is "unjust, unreasonable, unduly discriminatory, or preferential,"

21. The drafters "recognize[d] the need for private contracts of varying terms," United Gas Pipc Line Co. v. Mobile Gas Serv. Corp., 350 U.S. 332, 345 (1956), and attempted to preserve "the 'integrity' of private contractual arrangements." United Gas Pipe Line Co. v. Memphis Light, Gas \& Water Div., 358 U.S. 103, 114 (1958).

22. See United Gas Pipe Line Co. v. Mobile Gas Serv. Corp., 350 U.S. 332, 338 (1956), where the court contrasted the rate-making procedures used by the FPC with those used by the Interstate Commerce Commission (ICC). Unlike the FPC, the ICC does not allow rates to be set by private contracting, but instead requires uniform rates. Id.

23. Natural Gas Act $\S 4,15$ U.S.C. $\S 717(c)$ (1970). For a discussion of the Commission's powers under section 4, see generally FPC v. Hunt, 376 U.S. 515, 521-22 (1964).

Courts have analogized the FPC's power to curtail gas deliveries with the Commission's power to abrogate rate provisions. See Atlanta Gas Light Co. v. Southern Natural Gas Co., 338 F. Supp. 1039 (N.D. Ga. 1972), aff'd in part, vacated and remanded in part, 476 F.2d 142 (5th Cir. 1973).

24. Under the optional pricing procedure, producers can charge rates established by contract even if above the area rate cciling. If the higher prices are later disapproved by the FPC, the producer does not have to make refunds or continue supplying gas at reduced rates. Instead, the producer may decide either to withdraw the gas from the market or to sell in the future at the approved price. If area rates are later raised above the contract price, the producer remains bound by his contract. This option was designed to reduce the uncertainty as to rates which discourages producers from committing new reserves to interstate service. See generally FPC Order No. 455-A, 37 Fed. Reg. 18,721 (1972); FPC Order No. 455, 37 Fed. Reg. 16,189 (1972).

25. Section 7 of the Natural Gas Act, 15 U.S.C. $\$ 717 f$ (1970), outlines procedures for initiating service to new customers and for terminating existing customers.

26. Natural Gas Act § 4, 15 U.S.C. \$ 717c (1970).

27. $I d . \S 717 \mathrm{~d}$. 
sion to make appropriate modifications. ${ }^{28}$ Such modification may even include FPC-ordered refunds where the rates charged are later found to be unjust or unreasonable. ${ }^{29}$

The authority of the FPC to abrogate contracts in furtherance of its regulatory powers has long been recognized as including the power to ration a short supply of gas and to order curtailed deliveries to certain customers despite existing contract obligations. ${ }^{30}$ The courts, however, have not been consistent in indicating which section of the Natural Gas Act provides the basis for such authority. Two decisions ${ }^{31}$ have based the FPC's power to curtail on section 7(b), which provides, inter alia, for regulation of service abandonment where gas supplies are depleted or where required by public convenience and necessity. $^{32}$ Since curtailment does not involve a total termination of service, the Sixth Circuit has held that the FPC's curtailment authority is based in sections 4 and 5 of the Act. ${ }^{33}$ Section $4^{34}$ prohibits any grant of an "undue preference or advantage" in the transportation or sale of gas, and section $5^{35}$ provides for hearings prior to the formulation of a curtailment plan to prevent such undue preference. It is argued that the exercise of the Commission's jurisdiction over the "transportation of natural gas in interstate commerce"36 by allocation of a short supply of gas is necessary in order to prevent "undue preference[s]" or "unreasonable difference[s] in service" which are prohibited by sections 4 and $5 .^{37}$ Regardless of whether the FPC's power

28. Perhaps the philosophy behind this "abrogation concept" is best exemplified by United Gas Pipe Line Co. v. Mobile Gas Serv. Corp., 350 U.S. 332 (1956). Despite its holding, which tended to preserve the integrity of contracts, Mobile acknowledged that "contracts remain fully snbject to the paramount power of the Commission to modify them when necessary in the public interest." Id. at 344.

29. See Natural Gas Act $\$ 4,15$ U.S.C. $\$ 717$ c (1970). See generally Note, FPC Refund Powers Under the Natural Gas Act, 1972 Duke L.J. 203.

30. See, e.g., Panhandle E. Pipe Line Co. v. Public Serv. Comm'n, 332 U.S. 507, 523 (1947) (FPC shares power with the states to curtail direct sales to industry); Atlanta Gas Light Co. v. Sonthern Natural Gas Co., 338 F. Supp. 1039, 1046 (N.D. Ga. 1972) (FPC has exclusive jurisdiction to regulate curtailments of sales for resale).

31. See Panhandle E. Pipe Line Co. v. Michigan Consol. Gas Co., 177 F.2d 942 (6th Cir. 1949); Michigan Consol. Gas Co. v. FPC, 203 F.2d 895 (3d Cir. 1953).

32. 15 U.S.C. \& $717 f(b)(1970)$.

33. Curtailment was upheld on this basis in Michigan Consol. Gas Co. v, Panhandle E. Pipe Line Co., 226 F.2d 60 (6th Cir. 1955), and Michigan Consol. Gas Co. v. Panhandle E. Pipe Line Co., 173 F.2d 784 (6th Cir. 1949).

34. 15 U.S.C. \& $717 c$ (b) (1970).

35. $I d . \$ 717 \mathrm{~d}$.

36. Natural Gas Act § 1(b), 15 U.S.C. § 717(b) (1970).

37. Until recently the FPC did not assert jurisdiction to curtail direct sales as well as sales for resale. See United Gas Pipe Line Co., No. 71-120 (F.P.C. Op. No. 606, 
to curtail is based on section 7 or on sections 4 and 5 , it is nevertheless clear that the power is now well-established.

\section{Defenses to Suits by Curtailed Customers FOR BREACH OF CONTRACT}

Until now, the question of whether or not a pipeline company may be held liable for breach of contract when it has curtailed its gas deliveries pursuant to FPC order has not been fully hitigated. As in the past, the customers involved in the latest litigation prompted by curtailment activity have concerned themselves primarly with the manner in which the gas was to be allotted, leaving the more basic question of a pipeline's liability in damages in the background. ${ }^{38}$ Nevertheless, the question has arisen and pipeline companies must construct arguments for freeing themselves from liability in situations where they are not at fault. This may be done through the use of both statutes and the common law. ${ }^{39}$

\section{Common Law Defenses to Liability}

The common law recognizes impossibility of performance as a defense to suits for breach of contract. ${ }^{40}$ Thus, at common law, it may

Oct. 5,1971$)$. Doubt as to the existence of jurisdiction over direct sales arose because of the language of section 1(b) of the Natural Gas Act stating:

... [T] his chapter shall apply to the transportation of natural gas in interstate commerce, to the sale in interstate commerce of natural gas for resale ... but shall not apply to any other transportation or sale of natural gas . . . 15 U.S.C. \& 717 (b) (1970).

The Supreme Court has upheld the FPC's jurisdiction under section 1(b) to regulate curtailment of direct sales, but has withheld the authority to set rates for direct sales. FPC v. Louisiana Power \& Light Co., 406 U.S. 621 (1972).

38. See Monsanto Co. v. FPC, 463 F.2d 799 (D.C. Cir. 1972); United Gas Pipe Line Co., No. 71-120 (F.P.C. Op. No. 606, Oct. 5, 1971). See notes 14 \& 18 supra and accompanying text.

39. See, e.g., International Paper Co. v. FPC, 476 F.2d 121 (5th Cir. 1973), where the court compared the two opinions in United Gas. The court observed that FPC Op. No. 606 recognized as applicable the common law impossibility defense to a breach of contract suit, while FPC Op. No. 606-A would support a defense on the statutory basis of the Natural Gas Act's grant to the FPC of the power to abrogate contract provisions where necessary to prevent "undue preference." See 15 U.S.C. $\S 717$ (c) (1970). However, it is not clear that 606-A relied upon different grounds than did 606 in recoguizing a defense to a breach of contract action. In 606-A the Commission merely sought to clarify the ruling and rationale of 606. No. 71-120, at 3 (F.P.C. Op. No. 606-A, Dec. 3, 1971).

40. See generally 6 CORBIN $\S \$ 1320-1352$; GotTSChalK, IMPOSSIBILITY OF PERFORMANCE IN CONTRACT (1938); McElroy, IMPossibility of Performance (1941); Restatement \$§ 454-69; Sawada, SubSequent Conduct and Supervening Events (1968); 6 WILLISTON $\S \S 1931-1974$. 
be argued in defense of a curtailing pipeline company that a shortage of natural gas and the resulting FPC curtailment orders rendered performance impossible, and that the pipeline should therefore be free from liability. There are two branches of the impossibility doctrine applicable to the natural gas situation: impossibility due to destruction of the subject matter of the contract, and prevention of performance by supervening change of law or by administrative order. The defense of impossibility is based on the theory of implied condition, where the contract, though absolute on its face, is read as if it contained a clause excusing performance when certain circumstances render performance impossible. ${ }^{41}$

Under the first branch of the doctrine, where a contract assumes continued existence or availability of a specific thing, the destruction of the thing or its unavailability before the time of performance will excuse nonperformance. ${ }^{42}$ This defense assumes an absence of both the fault of the nonperforming party and any provision in the agreement for one of the parties to be responsible for the continued existence of the subject matter. ${ }^{43}$

Bruce v. Indianapolis Gas Co.44 exemplifies the application of this doctrine to the problem of an unanticipated shortage of gas. In Bruce, the defendant contracted to lay gas mains and connect them with certain lots. The Indiana Court of Appeals found that the contract was conditioned, in the contemplation of the parties, upon the continued existence of a supply of natural gas. Therefore, the court held that the contractor was not liable for nonperformance occasioned by failure of the gas supply, absent fault on his part in creating the shortage or a provision for substituted performance. ${ }^{45}$ Similarly, in Housing Authority of Bristol v. East Tennessee Light and Power Co., ${ }^{46}$ the Supreme Court of Appeals of Virginia excused a utility company from performing a contract to supply gas where the supply was prematurely exhausted, saying, "both parties did, in fact, contemplate the continued existence of a nearby gas deposit as a means of performance, that deposit being the only one known to this section of the country." ${ }^{\prime 7}$

41. See generally 6 WILLISToN $\S 1937$. See also La Cumbre Golf and Country Club v. Santa Barbara Hotel Co., 205 Cal. 422, 271 P. 476 (1928); Gibbs v. Hersman, 73 Cal. App. 732, 239 P. 350 (1925).

42. See, e.g., Taylor v. Caldwell, 122 Eng. Rep. 309 (1863).

43. See notes 60-64 infra and accompanying text.

44. 46 Ind. App. 193, 92 N.E. 189 (1910).

45. Id. at 199,92 N.E. at 191.

46. 183 Va. 64,31 S.E.2d 273 (1944).

47. Id. at 74,31 S.E.2d at 277 . 
Where performance is only partially prevented by a shortage of a commodity, the excuse of impossibility is also a defense for partial nonperformance. ${ }^{48}$ Where a supply of a commodity is insufficient to meet the demand, the common law provides for prorating the available supply, ${ }^{49}$ and the supplier remains bound by his distribution contracts to the extent that performance is practicable and a supply is available. ${ }^{50}$ Methods of rationing may differ, and a proper scheme does not necessarily require an equal share for each customer, since preferences for certain uses may be justified by compelling social needs. ${ }^{61}$ When rationing is allowed, and the supplier fails to deliver the entire prorated amount, the measure of damages against the supplier is not computed with respect to the amount of the coinmodity to be delivered according to the original contract; instead, damages are based upon the customer's fair quota under the proration. ${ }^{.2}$ If the supplier delivers the entire amount required under the proration, he is subject to no liability whatsoever. Assuming that FPC curtailment is not a defense, this theory would seem to be adaptable to the current gas shortage situations in which insufficient gas supplies must be prorated. ${ }^{53}$

According to the second major branch of the doctrine, the common law also recognized a defense of impossibility where, absent a contrary expressed intention of the parties and absent contributing fault by the party charged with performance, a change of law, a judicial decision, or an administrative order prevents performance of the contract. ${ }^{54}$ Here the rationale is that to hold a promisor liable for failing to perform his promise after the law has prohibited its performance would be inequitable. ${ }^{55}$ Nevertheless, this defense unay be unavailable where the party relying on the defense has taken an active role in inducing the change. ${ }^{56}$

48. See 6 CoRBIN \& 1342; RESTATEMENT \& 463.

49. See Consolidation Coal Co. v. Peninsular Portland Coal Co., 272 F. 625 (6th Cir. 1921); Nicoll v. Pittsvein Coal Co., 269 F. 968 (2d Cir. 1920); 6 CorbiN $\S 1342$.

50. See 6 CORBIN $\S 1342$. Proration is thus justified where custoin or contract shows that the party did not assume the risk. The nonperforming party has the burden of showing that the method of prorating was fair and reasonable and carried out in good faith. Id.

51. Id. at 414-15.

52. See, e.g., Indiana Flooring Co. v. Grand Rapids Trust Co., 20 F.2d 63 (6th Cir. 1927); Consolidation Coal Co. v. Peninsular Portland Cement Co., 272 F. 625 (6th Cir. 1921); Haley v. Van Lierop, 64 F. Supp. 114 (W.D. Mich. 1945).

53. See note 38 supra and accompanying text.

54. See 6 CoRbin $\$ 1346$; Restatement $\$ 458 ; 6$ WiLliston $\S \S 1938-39$.

55. See, e.g., Jackson \& Co. v. Royal Norwegian Gov't, 177 F.2d 694 (2d Cir. 1949); 6 WILLISTON $\$ 1938$.

56. In the case of a judicial order, it is generally accepted that an injunction re- 
The doctrine of impossibility due to contrary government order has been readily applied to the area of regulated industries, ${ }^{57}$ including the area of gas contracts. In the English decision of Leiston Gas Co. v. Leiston-Cum Sizewell Urban District Council, ${ }^{58}$ a gas company contracted not only to supply gas but also to maintain gas liglits for a fixed fee. Due to wartime conditions, a subsequent government regulation forbade the lighting of street lamps. In an action by the gas company for payment according to the terms of the contract, the English Court of Appeals awarded the desired relief, holding that delivery of the gas, in light of the gas coinpany's other duties, was not a condition precedent to payment. More importantly, the court further stated that the gas company could not be held liable on a counterclaim for dainages for not supplying gas, since performance was prevented by governmental order. ${ }^{59}$

As noted above, the applicability of either type of impossibility defense is limited by several factors. First, the contingency which prevents performance must be one which the parties had no reason to anticipate. ${ }^{60}$ Secondly, contrary legal order or destruction of subject

sulting from private litigation will not excuse nonperformance if the injunction was sought by the party seeking to be excused. See Peckham v. Industrial Sec. Co., 31 Del. 200, 113 A. 799 (Super. Ct. 1921). Where the promisor is active in bringing about a change in the law, such change may still excuse his nonperformance. See 6 Winliston $\$ 1938$, at 5429 n.9. See also Board of Comm'rs. v. Young, 59 F. 96, 108 (6th Cir. 1893); Nitro Powder Co. v. Agency of Canadian Car \& Foundry Co., 223 N.Y. 294, 135 N.E. 507 (1922). This may not be the case, however, when the promisor mduces a change by private act or by administrative or executive order. See generally 6 WILIISTON $\$ 1939$, at 5433 n.3. See also The Marpesia, 292 F. 957 (2d Cir. 1923). But see Primos Chem. Co. v. Fulton Steel Corp., 266 F. 937 (N.D.N.Y. 1920).

57. See, e.g., New York Trust Co. v. SEC, 131 F.2d 274 (2d Cir. 1942) (illegality because of a new concept of public policy adopted by the SEC held to strengthen the defense of impossibility due to failure of the subject matter); Gillies v. La Mesa Lemon Grove and Spring Valley Irr. Dist., 54 Cal. App. 2d 756, 129 P.2d 941 (1942) (violation of terms of a contract setting rates held not grounds for an action for damages where rates were superseded by rates established by a governmental commission); Wolverine Natural Gas Corp. v. Consumers Power Co., 296 Mich. 500, 296 N.W. 660 (1941) (failure by buyer to purchase full amount for which he contracted held to result in no hability where an order of a governmental commission prevented the fulfillment of the contractual obligations).

58. [1916] 2 K.B. 428 (C.A.).

59. Id. at 439 .

60. See Oliver-Electrical Mfg. Co. v. I.O. Teigen Constr. Co., 177 F. Supp. 572 (D. Minn. 1959); Hein v. Fox, 126 Mont. 514, 520, 254 P.2d 1076, 1079 (1953); Western Drug Supply \& Specialty Co. v. Board of Admin., 106 .Kan. 256, 262, 187 P. 701, 704 (1920).

The unforeseeability requirement may thus make the defenses of inpossibility less appropriate if shortages becoine routine. 
matter is no defense when the risk was specifically placed on the promisor, ${ }^{61}$ since the law does not prohibit the inaking of a contract in which the parties bind themselves to perform what in fact is or may become impossible. $^{62}$ Such provisions may be imphed froin the circumstances surrounding the formation of the contract. ${ }^{83}$ Finally, no defense of impossibility is available under any circumstances where the preventing contingency is the result of the fault or action of the nonperforming party..$^{64}$

\section{Statutory Defenses to Liability}

In addition to the common law defense of impossibility of performance due either to failure of subject matter or to govcrnmental action, immunity to suit for breach of contract where performance is impossible is often granted by statute. For example, the Uniform Commercial Code (UCC) provides for a defense of impossibility when, due to an unforeseen change in circumstances, the nonoccurrence of which was a basic assumption on which the contract was made, performance becomes impossible. ${ }^{65}$ In other specific areas, where administrative officers possess statutory power to regulate the supply or use of certain

61. Concerning contrary legal orders, see Inter-coast S.S. v. Seaboard Transp. Co., 291 F. 13 (1st Cir. 1923); City of Topeka v. Industrial Gas Co., 135 Kan. 646, 11 P.2d 1034, cert. denied, 287 U.S. 658 (1932); 6 WIILISTON \& 1939.

Concerning destruction of subject matter, see 6 WIILISTON $\$ \S 1934,1972 A$. See also Columbus Ry., Power \& Light Co. v. City of Colunbus, 249 U.S. 399 (1919); E.W. Bliss Co. v. Buffalo Tin Can Co., 131 F. 51 (2d Cir. 1904).

62. See Restatement \& 456 for examples of cases where parties contractually bind themselves to perform what may become impossible. One such example is as follows: if $A$ contracts to sell $B$ a specific horse and warrants that the horse is sound, when in fact the horse at the time is unsound, $\mathrm{A}$ is bound by the warranty, since he contracted to bear the risk.

63. See id., Explanatory Notes $\S 456$, comment (c) at 847 .

64. See generally 6 CoRBIN $\$ 1329$. See also Crown Embroidery Works v. Gordon, 190 App. Div. 472, 180 N.Y.S. 158 (1920).

65. UNIFORM COMMERCIAL CODE $§ 2-615$. This section excuses such nonperformance when it results froin "a contingency the non-occurrence of which was a basic assumption on which the contract was made or by compliance in good faith with any applicable foreign or domestic governinental order whether or not it later proves to be invalid." Id. The Code also provides for an assumption of a greater obligation and for allocation of a short supply in a fair and reasonable manner. Id. In particular, the UCC provision covers the loss of an exclusive or contemplated source of supply. Id., comments 4-5.

In Gardiner v. Philadelphia Gas Works, $413 \mathrm{~Pa} .415,417-19,197$ A.2d 612, 613-14 (1964), the court stated that a contract to deliver gas to a customer's home on a month-to-month basis was a contract to sell goods under UCC $\$ 2-106$. Although gas may fall within the scope of the Code's definition of goods, see UCC $\$ \$ 2-105$, -107 , the fact that the natural gas industry is highly regulated may affect the applicability of the Code to sales of natural gas. 
commodities, thereby having the potential to make performance of a contract impossible, the authorizing statutes sometimes expressly provide for a defense of impossibility in an action against the contractor for nonperformance. ${ }^{66}$ Thus, in L.N. Jackson \& Co. v. Royal Norwegian Government, ${ }^{67}$ the Second Circuit excused nonperformance of a contract to deliver a commodity where performance was prevented by order of the U.S. Maritime Commission, whose authorizing statute einpowered it to insulate contractors from liability for a breach of contract caused by compliance with the Commission's orders. ${ }^{68}$ It could be argued that the failure of Congress to pass such a section in the Natural Gas Act indicates an intention that no defense should exist outside the statute. The court in Jackson, however, concluded that the statutory defense merely reinforced the common law defense. ${ }^{69}$ In any event, the failure of Congress to provide expressly for pipeline immunity in a curtailment situation is probably a doubtful index of congressional intent to impose liability on the pipelines. ${ }^{70}$

While the above statutory and common law defenses are potentially applicable to the FPC gas curtailment problein, not all have been effectively utilized in past curtailment situations. There are three principal explanations for this. First, as indicated above, the Natural Gas Act provides no statutory defense for curtailing pipelines to breach of contract actions by their customers. Moreover, the UCC was not uniformly adopted until after the occurrence of previous curtailment suits. Nevertheless, the UCC might provide an argument by analogy be-

66. See 6 Corbin $\S 1346$, at 433 n. 42 citing examples of such statutes. For example, the English Ministry of Supply Act (1939) $\$ 7(7)$ provides: "where the failure to fulfill any contract, whether made before or after the commencement of this Act, is due to compliance with directions given by the Minister of Supply under this section, proof of that fact shall be a good defense to any action or proceeding in respect of the failure." See also Denny, Mott \& Dickson, Ltd. v. Fraser \& Co. [1944] 1 All E.R. 678 (C.A.).

67. 177 F.2d 694 (2d Cir. 1949).

68. Id. When World War II erupted, the U.S. Maritime Commission ordered the Royal Norwegian Government to substitute wool for the copra which they had contracted to transport pursuant to an Act of May 31, 1941, ch. 157, 55 Stat. 236, which read: "No person, firm, or corporation shall be held liable for damages or penalties for any default under any contract or order which sluall result directly or indirectly from his compliance with any rule, regulation, or order issued under this section." The above statute was later amended to provide insulation whether or not the regulations were later declared to be invalid. Second War Powers Act, ch. 199, tit. III, § 2(a)(7), 56 Stat. 180 (1942). This is similar to $\$ 2-615$ of the UCC, see note 65 supra and accoinpanying text. The legislative history of the above insulating statute suggests that Congress felt a need for such affirmative protection to assure insulation from liability. H.R. ReP. No. 460, 77th Cong., 1st Sess. 4 (1941).

69. 177 F.2d at 701.

70. See, e.g., Helvering v. Hallock, 309 U.S. 106, 119-20 (1940). 
cause the gas industry, being highly regulated, only partially relies on private contracts covered by the Code. ${ }^{71}$ Secondly, the defense of impossibility due to failure of the subject matter has not been used in cases of FPC-regulated curtailments. This is perhaps due to the difficulty in visualizing national gas reserves as analogous to the individual wells and regional fields which constituted the basis of the prior use of the defense, ${ }^{72}$ for it is certainly much easier to determine when a single well has run dry than to determine that a given pipeline has no gas available to it from the entire national reserves. Finally, the defense of impossibility due to contrary governmental order has not been expressly adopted by the courts. However, this defense may nevertheless be the conceptual basis underlying judicial refusal to take jurisdiction of suits for breach of contract or to grant specific performance or damages in cases where FPC curtailment orders were followed. ${ }^{73}$

\section{Previous Sutts to ENForce Contracts FOLLOWING FPC CURTAILMENT}

The majority of the litigation concerning rights under FPC curtailment plans has taken place in the federal courts. ${ }^{74}$ However, these cases have involved questions of primary jurisdiction and exhaustion of remedies in the delineation of rights following FPC curtailment proceedings. ${ }^{75}$ As a result, the federal courts have not yet fin-

71. See note 65 supra and accompanying text.

72. See notes $46-47$ supra and accompanying text.

73. The defense of impossibility of performance due to intervening governmental order was specifically recognized in dicta in International Paper Co. v. FPC, 476 F.2d 121 (5th Cir. 1973). The concurring judge would have based exoneration instead on what the judge referred to as "the intrinsic power of the federal government to preempt and abrogate private agreenents in the interest of the public weal." The "mere contractual defense of impossibility of performance due to intervening governmental order" was expressly repudiated. Id. at . However, it is hard to see how this would be anything but the impossibility doctrine under another label.

74. Most of the cases arising from contract disputes subsequent to FPC curtailment have fallen under the federal courts' diversity jurisdiction, 28 U.S.C. $\$ 1332$ (1970). See, e.g., FPC v. Louisiana Power \& Light Co., 406 U.S. 621 (1972); Panhandle E. Pipe Line Co. v. Michigan Consol. Gas Co., 177 F.2d 942 (6th Cir. 1949); Michigan Consol. Gas Co. v. Panhandle E. Pipe Line Co., 173 F.2d 784 (6th Cir. 1949).

If diversity is not present, it is difficult to establish federal jurisdiction since an action for damages for breach of contract usually is governed by state law pursuant to Erie R.R. v. Tompkins, 304 U.S. 64 (1938). Anticipation of a federal defense such as the defense of FP.C-ordered curtailment, is inadequate to raise federal question jurisdiction. See Pan American Petro. Corp. v. Superior Court, 366 U.S. 656 (1961); Louisville \& Nashville R.R. v. Mottley, 211 U.S. 149 (1908); Georgia v. Southern Ry., 25 F. Supp. 630 (N.D. Ga. 1938). But see Simpson v. South Western R.R., 231 F.2d 59 (5th Cir. 1956).

75. See, e.g., Interstate Natural Gas Co. v. Southern Cal. Gas Co., 209 F.2d 380 
ally decided the question of whether or in what circumstances a pipeline will be liable for breach of contract following an FPC-ordered curtailment. Jurisdictional difficulties have been especially apparent in such suits when the remedy sought was specific performance or injunctive rehef. Such relief would effectively nullify the power of the FPC to exercise its jurisdiction to regulate the allocation of gas by ordering the curtailment plans during periods of shortage. As a result, the courts have consistently dismissed suits to obtain specific performance in violation of FPC-ordered curtailments. ${ }^{76}$

While the granting of specific performance would totally negate the power of the FPC to order curtailments, the effect upon the FPC of granting damages to customers whose gas has been curtailed nay not be as direct or harmful, for an award of damages could be granted to an aggrieved customer while upholding the curtailment order. Moreover, it does not necessarily follow that, because it is in the public interest to curtail gas deliveries, it is also in the public interest to grant the curtailing pipeline immunity from liability in damages. ${ }^{77}$ No. clear picture emerges from the disposition of past actions seeking damages for breaches occurring as a result of an FPC-approved pipeline cur-

(9th Cir. 1953) (suit for damages held within FPC's primary jurisdiction); Michigan Consol. Gas Co. v. Panhandle E. Pipe Line Co., 173 F.2d 784 (6th Cir. 1949) (suit for specific performance dismissed for failure to exhaust administrative remedies). See also Atlanta Gas Light Co. v. Southern Natural Gas Co., 338 F. Supp. 1039, 1050 (N.D. Ga. 1972), affd in part, vacated and remanded in part, 476 F.2d 142 (5th Cir. 1973) (discussion of "exclusive jurisdiction"). For a discussion of primary jurisdiction and exhaustion of remedies, see $3 \mathrm{~K}$. Davis, Administrative Law Treatise $\S \S 19.01-20.10$ (1958).

It is presently unclear to what extent questions of fact and law in disputes over contract rights are to be resolved by the FPC and to what extent they are to be resolved by the courts. Compare Michigan Consol. Gas Co. v. Panhandle E. Pipe Line Co., 226 F.2d 60, 70 (6th Cir. 1955), stating that the question whether a gas shortage is the result of pipeline negligence is to be decided by the FPC, with United Gas Pipe Line Co., No. 71-120, at 23 (F.P.C., July 3, 1972) (presiding examiner's initial decision on remanded issues), in which the FPC disclaims such jurisdiction. Although the court in Panhandle stated that the question of negligent causation was to be decided by the Commission, it stated that the question of compliance was to be decided by the court. 226 F.2d at 70-71. The court indicated that those questions of law and fact which required technical expertise and the exercise of administrative power and discretion for their resolution were to be decided by the Commission, and those questions which did not were to be decided by the court. Id.

76. See Michigan Consol. Gas Co. v. Panhandle E. Pipe Line Co., 173 F.2d 784 (6th Cir. 1949). See also Panhandle E. Pipe Line Co. v. Michigan Consol. Gas Co., 177 F.2d 942 (6th Cir. 1949).

77. See International Paper Co. v. FPC, 476 F.2d 121 (5th Cir. 1973), where the court points out that the issue of whether the right to sue for damages due to a curtailment order is contrary to the public interest must be dealt with separately from the issue of whether or not curtailment is in the public interest. 
tailment, ${ }^{78}$ but the cases indicate that a suit for damages may encounter the same jurisdictional barriers as a suit for specific performance.

This is exemplified in Atlanta Gas Light Co. v. Southern Natural Gas Co., ${ }^{79}$ a recent curtailment suit in which money damages, injunctive and declaratory relief, and specific performance were sought. This case arose out of a curtailment which was imstigated by Order No. 431, under which Southern and other pipelines were required to submit curtailment plans to the FPC. ${ }^{80}$ The district court held that since the breach was not unilateral, but was initiated by FPC curtailment, the district courts could not assume jurisdiction of the case. ${ }^{81}$ The Atlanta Gas court therefore dismissed the entire suit including the damage claim. ${ }^{82}$

A sinilar jurisdictional hurdle was imposed in Interstate Natural Gas Co. v. Southern California Gas Co. ${ }^{83}$ a case in which a suit for damages against a pipeline company subject to agency regulation was dismissed as a collateral attack against administrative action. In this case a pipeline company contracted with a customer to carry the customer's gas exclusively, to the full extent of the pipeline's capacity. Another natural gas company, wishing the pipeline to carry its gas, claimed the pipeline company was obligated under federal law to

78. This is perhaps because aggrieved parties have been more concerned with determining how the much-needed gas was to be allotted and because suits remanded to the FPC as being within the Commission's primary jurisdiction were never forced to a fimal resolution because of the temporary nature of prior gas shortages and the continuing nature of the relationship among the parties. But see Michigan Consol. Gas Co. v. FPC, 283 F.2d 204 (D.C. Cir. 1960), for a discussion of the longstanding series of court actions between the two parties.

79. 338 F. Supp. 1039 (N.D. Ga. 1972), aff'd in part, vacated and remanded in part, 476 F.2d 142 (5th Cir. 1973).

80. See notes 7-10 supra and accompanying text.

81. Had the breach been unilateral, the case may have fallen under the jurisdiction of the court within a limited exception to the exclusive jurisdiction of the FPC over sales for resale carved out by United Gas Pipe Line Co. v. Memphis Light, Gas, and Water Div., 358 U.S. 103 (1958), and United Gas Pipe Linc Co. v. Mobile Gas Serv. Corp., 350 U.S. 332 (1956). Furthermore, unlike Atlanta Gas, both Memphis and Mobile had proceeded through the FPC to review in the courts of appeals, and were not originally brought in the district court. See generally 338 F. Supp. at 1048.

82. On appeal, the Fifth Circuit vacated the portion of the court's order dismissing the suit for damages, holding that the claim should have been retained within the court's jurisdiction pending final determination by the Coinmission of the validity of the curtailment plan involved. The court declimed to comment upon the merits of the claim or upon what issues would be open to the court once the validity of the curtailment plan had been finally determined. Atlanta Gas Light Co. v. Southern Natural Gas Co., 476 F.2d 142 (5th Cir. 1973). This treatment is similar to that given the claim for damages in Monsanto Co. v. FPC, 463 F.2d 799, 806 (D.C. Cir. 1972). 83. 209 F.2d 380 (9th Cir. 1953). 
operate as a common carrier and brought suit for damages against the pineline company when the pipeline refused to act accordingly. Since the existing contract had FPC approval, the suit was held to be, in effect, a collateral attack upon FPC action and was therefore dismissed. ${ }^{84}$

The most extreme example of the courts' reluctance to impose damages upon a pipeline for breach of contract brought about by curtailment arose in Panhandle Eastern Pipe Line Co. v. Michigan Consolidated Gas Co., ${ }^{85}$ where the court refused to enforce a contractual provision holding Panhandle hable for nondelivery of gas since the provision did not specifically provide for FPC-imposed curtailments. Panhandle was a case in which the question of damages was considered on a claim by a utility against a pipeline for revenue lost because of a decrease in sales due to an FPC curtailment. The district court held against the utility, stating that:

To hold [the pipeline company] liable in damages . . . is but another way of regulating activities which Congress has entrusted to the Commission. Any private remedies . . . unust give precedence to the regulatory powers of the Commission and [the customer] must secure Commission sanction for damages claims as well as claims for specific enforcement .... O Otherwise, [the pipeline] may be penalized for alleged failure to perform its contract when such performance would have been contrary to the public interest and forbidden by the Coinmission. ${ }^{36}$

On appeal, the Court of Appeals for the Sixth Circuit held that the district court had jurisdiction over the utility's claim and that the pipeline would be liable for breach if it violated the Commission's order. ${ }^{87}$ On remand, however, the district court found that there had been coinpliance with the FPC curtailment order and ruled that the customer therefore could recover nothing on its claim for damages despite the presence of the provision lrolding Panhandle liable for nondelivery. ${ }^{88}$ Thus, since the pipeline had not caused the shortage and the curtailment order was properly followed, the liability clause found in the con-

84. See also Bower v. Eastern Airlines, 214 F.2d 623 (3d Cir.), cert. denied, 348 U.S. 871 (1954); Applewhite v. Jones, 207 F.2d 701 (7th Cir.), cert. denied, 347 U.S. 954 (1954); United Merchants \& Mfrs., Inc. v. South Carolina Elec. \& Gas Co., 208 F.2d 685 (4th Cir. 1953); 2 K. Davis, Administrative LaW Treatise $§ 18.10$ (1958).

85. 226 F.2d 60 (6th Cir. 1955), cert. denied, 350 U.S. 987 (1956).

86. Panhandle E. Pipe Line Co. v. Michigan Consol. Gas Co., 117 F. Supp. 551, 560 (E.D. Mich. 1953).

87. Michigan Consol. Gas Co. v. Panhandle E. Pipe Line Co., 226 F.2d 60, 71 (6th Cir. 1955), cert. denied, 350 U.S. 987 (1956).

88. 173 F. Supp. 738 (E.D. Mich. 1959). 
tract was unenforceable. ${ }^{89}$ Accordingly, even a reimbursement clause, if generally worded, would not give rise to damages if the pipeline complied with FPC orders. These cases that liave reached the merits seem to indicate rather strongly that courts may be just as reluctant to award damages as they are to grant specific performance where contract performance has been impaired by FPC curtailment orders.

\section{STANDARDS FOR DETERMINING LIABILITY}

Despite the past reluctance of the courts to impose liability in damages upon pipeline companies for breach of contract resulting from compliance with an FPC curtailment order, it cannot be assumed that the courts will continue similarly to protect the pipelines in the future. As has previously been observed, while a court's decree of injunctive relief or specific performance nullifies the FPC's power to meet gas shortage situations by curtailment, this problem is not as clearly present when a court simply awards damages for breach of contract. Also, it has not been clearly demonstrated that complete immunity of the pipeline to damage claims is in the public imterest. Finally, there is the language of the District of Columbia Circuit indicating that curtailment pursuant to an FPC order is not an absolute defense to an action for breach of contract. ${ }^{90}$ Accordingly, it is necessary to consider in whiat cases a pipeline company ought to be hable in damages when it is forced to curtail its deliveries.

Both the case law analyzed above and reconciliation of the FPC's language of absolute defense in Opimion $606^{91}$ with the seemingly contrary statements of the District of Columbia Circuit in Monsanto ${ }^{02}$ indicate that the availability of the pipeline's theoretical defenses, especially that of impossibility due to administrative order, may depend upon three factors: first, whether one of the parties expressly assumed the risk of an FPC-ordered curtailment; second, whether the pipelime properly allocated gas according to applicable common law standards or in compliance with the FPC order; and third, whether the pipeline was at fault in creating the gas shortage which made curtailment necessary. While it is likely that the presence of any of these three conditions may result in a pipeline's being held liable in damages, a number of factors will influence the extent to which each condition may

89. 226 F.2d at 71.

90. Monsanto Co. v. FPC, 463 F.2d 799, 808 (D.C. Cir. 1972). See notes 15-18 supra and accompanying text.

91. United Gas Pipe Line Co., No. 71-120 (F.P.C. Op. No. 606, Oct. 5, 1971). See notes 11-14 supra and accompanying text.

92. Monsanto Co. v. FPC, 463 F.2d 799, 808 (D.C. Cir. 1972). 
be found to be present and the specific likelihood that each factor, if found to be present, will lead to liability.

\section{Contractual Assumption of Risk and Its Impact Upon Liability}

Any equitable system of distributing an externally caused loss requires a consideration of the type of gas service for which the parties initially bargained. Gas contracts frequently contain clauses which distribute the risk of curtailment in the event of a general gas shortage. ${ }^{93}$ Such clauses may or may not explicitly provide for curtailment due to an FPC order. In addition, gas contracts can be categorized into those for "firm" service and those for "interruptible" service. ${ }^{94} \mathrm{In}$ terruptible service provides the customer with a reduced rate in return for an agreement that gas deliveries may be suspended during periods of peak demand. Interruption of service is to be distinguished from curtailment in that it usually results from natural seasonal fluctuations in demand rather than a general gas shortage and is routinely administered according to private contract terms rather than by FPC intervention in abrogation of contracts.

Where a contract expressly imposes upon a pipeline the risk of an FPC-ordered gas curtailment, it seems extremely likely that the pipeline would be held liable in damages to the customer in the event such a curtailment occurred. As the Panhandle ${ }^{95}$ litigation indicates, however, if the contract indemnification clauses do not specifically mention the contingency of FPC curtailment, their effectiveness in fixing liability may be limited to situations in which the pipeline is at fault either in causing the gas shortage or in failing to comply with the FPC allocation. This conclusion is supported by the FPC's recent Opin-

93. See id. at 801-02 n.4, for an example of such a modern contract provision:

Buyer specifically recognizes the fact that Seller dehivers gas to gas utilities for resale to domestic customers and to public power plants for generation of electricity which is sold to domestic customers. In the event a sliortage of gas renders Seller unable to supply the full gas requirements of all its consumers, then it is mutually agreed that the gas requirements of gas utilities selling gas to domestic consumers and public utility power plants using gas for generation of electricity which is sold to domestic customers shall first be supplied by Seller, and the remaining available gas shall be prorated by Seller among its other contract consumers, imcludimg Buyer.

Sucl provisions also often take the form of substitute fuel clauses in which the pipeline agrees to reimburse the customer for any premium which the customer must pay to obtain other fuel during periods im which the gas supply is interrupted. See International Paper Co. v. FPC, 476 F.2d 121, 123 n.1 (5th Cir. 1973).

94. Interruptible service contracts are usually entered into when the customer has certain alternative fuel sources available. For a discussion of firm and interruptible gas service, see Citizens Gas Co., 87 P.U.R. (n.s.) 145 (1951).

95. See notes 85-89 supra and accompanying text. 
ion $606-\mathrm{A},{ }^{96}$ which held that affirmative nullification by the Commission of such a general contract indemnification clause was not needed in the curtailment plan to assure the pipelines a defense from liability. Moreover, the Supreme Court has recognized that the possibility of inconsistent results with respect to pipeline liability stemming from giving effect to all diverse contractual provisions might be grounds for regulating in abrogation of such privately agreed-upon terms. ${ }^{97}$

On the other hand, the recent introduction by the FPC of its new optional pricing procedure, ${ }^{98}$ which relies on a concept of "sanctity of contract," would seem to indicate that even generally worded curtailment indemnification clauses might in the future be enforced to hold a pipeline liable for an FPC-ordered gas curtailment. While not directed towards the problem of curtailment, ${ }^{99}$ the optional pricing procedure indicates a policy on the part of the FPC to give maximum effect to private contractual provisions where, by so doing, such a policy will increase the supply of natural gas. If giving effect to indemnification clauses in private contracts for the supply of gas does not impair the Commission's ability to regulate the gas industry and does not aggravate the shortage situation, there seems to be little reason for judicial refusal to enforce such indemnification clauses.

The presence of a contractual provision providing for "firm" service would also seem to increase the likelihood of a pipeline's being held liable for an FPC-ordered curtailment. It has been held that Commission efforts to divert gas from firm customers violates section 7(a) of the Natural Gas Act by impairing the ability of a gas company to "render adequate service to its customers." 100 If such a contract provision is relevant to the question of whether the Commission's division of gas was proper, it would also seein to be relevant to determining whether

96. United Gas Pipe Line Co., No. 71-120, at 3 (F.P.C. Op. No. 606-A, Dec. 3, 1971).

97. See FPC v. Louisiana Power \& Light Co., 406 U.S. 621, 627 (1972). The FPC similarly refused to prorate an inadequate supply of gas without violation of any contractual provisions, since the resulting allocation might not conform with the priorities required by the public interest. United Gas Pipe Line Co., No. 71-120, at 12-13 (F.P.C. Op. No. 606, Oct. 5, 1971).

98. See uote 24 supra and accompanying text.

99. The Commission's willingness to sanction freedom of contract principles in its recently announced optional pricing procedures seems to be contrary to the discernible trend of the Commission to abrogate private contracts by curtailment. However, these two practices are actually addressed to two separate facets of the gas shortage problem: curtailment is designed to alleviate shortage conditions once in existence, while optional pricing procedures are designed to prevent shortages by encouraging the increased production of natural gas. FPC Order No. 455 (Aug. 3, 1972).

100. Granite City Steel Co. v. FPC, 320 F.2d 711, 713 (D.C. Cir. 1963). 
a pipeline company is liable for a curtailment of gas pursuant to an FPC order. Since the supply of gas may be so short as to require a curtailment and yet not short enough to satisfy the interruption clauses of all interruptible contracts, ${ }^{101}$ the pipeline's liability might depend upon how interruptible the contract intended the service to be.

Thus while the Panhandle court refused to enforce a generally worded curtailment indemnification clause, such clauses, and similar contract clauses such as those providing for "firm" or "interruptible" service, seem likely to have a significant, though uncertain, impact on a pipeline's liability for an FPC-ordered curtailment.

\section{Propriety of the Allocation of Gas and Its Impact Upon Liability}

It is likely that, absent fault on the part of the pipeline in creating a gas shortage and absent an enforceable contractual provision placing the risk of loss froin curtailment upon the pipeline, compliance with an FPC curtailment order will insulate the pipeline from liability. ${ }^{102}$ Nevertheless, it is possible that a pipeline could find itself in a situation in which curtailment prior to FPC approval was necessary. In such a case, the liability of the pipeline would be dependent upon the propriety of its allocation of available gas prior to the issuance of an FPC curtailment order. As was emphasized in the preceding discussion, the propriety of allocation may in part be determined by reference to the pipeline's various contracts with its customers. However, it may also be measured against both common law standards and allocation priorities used by the FPC in issuing its own curtailment plans.:

Where a pipeline must allocate insufficient supplies of gas, the common law provides for the avoidance of liability by a nonperforming party, if the pipeline rations the insufficient supply in a fair and reasonable manner and if the shortage has not been caused by the curtailing party's negligence. The application of the "fair and reasonable" standard involves the consideration of many factors in determining what priority is to be given to various customers in the scheme of allocation. These considerations imclude the determination of whether the curtailed party is a regular customer as opposed to an infrequent purchaser, a full requirements as opposed to a partial requirements customer, an old customer as opposed to a new one, a purchaser for re-

101. See Louisiana Power \& Light Co. v. FPC, 406 U.S. 621, 632 (1972).

102. See Michigan Consol. Gas Co. v. Panhandle E. Pipe Line Co., 226 F.2d 60, 70 (6th Cir. 1955), cert. denied, 350 U.S. 987 (1956). See notes 85-89 supra and accompanying text. 
sale as opposed to a direct user, and a firm as opposed to an interruptible customer. In addition, the finding of a fair and reasonable allocation entails consideration of the degree to which the customer has relied upon the supplier, the foreseeability of a shortage at the execution of the contract, and the type of end use, whether domestic or commercial and industrial, to which the gas will be put. ${ }^{103}$

When determining the proper allocation of insufficient gas supplies, the FPC is bound by the Natural Gas Act to ascertain whether a proposed allocation is equitable in light of the interests of the general public as well as the interests of gas customers. Thus the Commission takes into account the interests of the end user of the gas, if the pipeline's customer is a buyer for resale, and the need for products manufactured by producers who rely primarily on natural gas as a fuel. ${ }^{104}$ In this regard, the Commission has given preference to ultimate domestic use of natural gas, as opposed to industrial or commercial uses. ${ }^{105}$ The FPC has indicated that preference would also be given to old as opposed to new customers and firm as opposed to interruptible customers, insofar as these types of considerations are dispositive. ${ }^{108}$ The Commission has not yet considered the priorities of resale as opposed to direct customers or full as opposed to partial requirements customers.

When a pipeline is forced to curtail deliveries of gas due to shortage conditions prior to FPC approval of the curtailment plan, the question arises as to whether subsequent FPC approval of the plan would retroactively insulate the pipeline from liability were a court to find that the allocation violated common law standards. If such retroactive immunity were not available, the potential liability of the pipeline would be increased to the extent that the FPC delayed in releasing its own curtailment order. ${ }^{107}$

103. See 6 CORBIN $\$ 1342$. See notes $48-53$ supra and accompanying text.

104. See FPC v. Transcontinental Gas Pipe Line Corp., 365 U.S. 1, 1-20 (1961).

105. The categories of priorities in the United curtailment plan were, listed in order of highest priority: (1) domestic customers, (2) direct industrial customers, to the extent that they use gas as a raw material in creating an end product, (3) electrical generating stations serving domestic consumers, (4) all others. United Gas Pipe Line Co., No. 71-120, at App. A (F.P.C., July 3, 1972) (presiding examiner's imitial decision on remanded issues).

106. The availability of an alternative fuel source is a factor in determining whether a particular customer will be curtailed. See id. at 13. To the extent that customers who have paid a premium for firm service are nore unprepared to use alternative fuels, the FPC will probably give preference to these firm customers.

107. An analogous uncertainty exists in the context of FPC rate proceedings. Sec, e.g., Comment, FPC Natural Gas Allocation: Curtailment in Context, 50 TEx. L. REv. 1370, 1373-78 (1972) for a discussion of the delays involved in the Natural Gas Act 
Distinctions between curtailment prior to and subsequent to FPC action could become less significant if the FPC were to grant affirmative retroactive insulation from contract liability upon approval of the curtailment plan. In an analogous situation, the FPC has asserted the authority to permit a proposed pipeline rate increase, previously improperly refused, to become effective retroactively, ${ }^{108}$ and the Fifth Circuit has suggested that such retroactive increases would be valid. ${ }^{109}$ An extension of this principle to include retroactive insulation from hability could simplify questions of curtailment liability. However, this theory of retroactive FPC insulation from liability has not been considered by the courts, since the Commission has never asserted this authority even prospectively in the curtailment context. Even without affirmative insulation, an argument could be made for an analogous retroactive immunity where rationing was done according to a curtailment plan subsequently approved by the FPC or under a good faith attempt to properly allocate gas. The common law doctrine of rationing ${ }^{110}$ and considerations of fair play would support granting immunity in cases of good faith attempts to properly allocate gas and to receive expeditious FPC approval of such allocation.

It is thus clear that where a pipeline is forced to curtail its deliveries prior to FPC approval due to shortage conditions not resulting froin the fault of the pipeline, in the absence of a contractual provision, the propriety of the allocation of gas by the pipeline will determine whether the pipeline will be liable to its curtailed customers for breach of contract. Since the FPC has not yet asserted the power to insulate retroactively the pipeline from liability upon approval of the curtailment plan, and if the courts refuse to imsulate the pipelines retroactively, delays in approving the curtailment plan may aggravate the potential liability of the pipeline. Accordingly, in order to protect the pipeline from the imposition of liability for breach of contract, it may be necessary for the FPC to order, and for the courts to approve, insulation of the pipeline from liability where the curtailment plan is ultimately approved by the Commission.

pricing procedure. This problem may not be as critical in the curtailment area, however, since curtailment does not directly affect the immediate acquisition of current income as does the case of rate uncertainty. If liability is later placed on the pipeline, the loss may very well be passed on to the other customers. On the other hand, if a pipeline is insulated from liability, it does not matter what the final allocation will be, because the pipeline will be paid for all the gas delivered.

108. See Mobil Oil Corp. v. FPC, 469 F.2d 130, 137, 137 n.5 (D.C. Cir. 1972).

109. Hunt v. FPC, 306 F.2d 334, 345 n.2 (5th Cir. 1962).

110. See notes 51-53 supra and accompanying text. 


\section{Negligent Creation of a Gas Shortage as a Ground for Liability}

Probably the inost significant factor in the determination of pipeline liability is the issue of whether a pipeline company was at fault in causing the shortage resulting in curtailment. In Monsanto Co. $v$. $F P C$, ${ }^{111}$ for example, it was argued that the necessity for curtailment was the result of the assumption of new sales by the pipeline with full awareness of a developing gas shortage. The Commission contended that it was known to the pipeline that the new sales would preinaturely exhaust gas supplies that would otherwise have been sufficient to meet previously existing contract obligations. ${ }^{112}$ The problem with basing pipeline liability on the criterion of fault is that factual coinplexities make its ascertainment difficult.

It is not an easy matter to distinguish a bona fide gas shortage from one which is actually the result of a knowing or negligent deficiency in exploration, an overextension of new commitinents, or another shortage-inducing action on the part of the pipeline. Uncertainties inherent in the gas industry make difficult an accurate determination of the extent of blame for the unavailability of natural gas ${ }^{113}$ and the fair placement of that blame on the parties who should bear it. The future growth of the market for gas and the rates which may be charged in such markets constitute the first unknown factor encountered in attempting to detect pipeline negligence. ${ }^{114}$ These uncertain factors may inake it difficult to determine the urgency of exploration for new gas supplies and the extent to which such exploration will be profitable.

A second uncertainty involves the problem of determining the extent of present reserves. This uncertainty has a direct bearing on the gas industry's need to search for new reserves and on the foreseeability of future shortages. Unlike the state cases involving local supplies in which the depletion of wells and the accoinpanying impossibility of delivery presented easy questions of fact, ${ }^{115}$ cases dealing with the regulation of nationwide systeins where gas is known to be in the ground

111. 463 F.2d 799 (D.C. Cir. 1972).

112. Id. at 804. See also United Gas Pipe Line Co., No. 71-120, at 4 (F.P.C. Op. No. 606-A, Dec. 3, 1971); United Gas Pipe Line Co., No. 71-120, at 22 (F.P.C. July 3, 1972) (presiding examiner's initial decision on remanded issues). The possibility that the question of liability might turn on considerations of fault was also indicated in International Paper Co. v. FPC, 476 F.2d 121 (5th Cir. 1973).

113. At present, shortages are not the result of the disappearance of sources of extractable natural gas, but rather the result of the mere unavailability of extracted gas. See FPC Order No. 455 , at 4.

114. See generally FPC Order No. 455 (1972); Comment, supra note 107, at 1350.

115. See notes $44-47$ supra and accompanying text. 
(but is yet untapped) are much more difficult to resolve since they do not imvolve easily identifiable markets or supplies. A related uncertainty facing both the pipelines and those who would determine the fault of the pipelines is the extent and cost of the exploration necessary to locate sufficient new reserves. The unpredictability of these many factors makes it extrenely difficult to attribute failure to discover new reserves to the negligence of any party.

All of these problems are coinplicated by the dichotomy between the pipeline industry and the gas-producing industry. While the same company may sometimes perform both functions of producing and transporting, the fact that pipeline companies are not necessarily directly responsible for the discovery of gas and its introduction into the pipelines complicates the fixing of the blane on the pipelines for an insufficient supply. Even if all indications are that a pipeline is at fault in causing a gas shortage which disables it from performing its contract obligations, the above intricacies would make proof of such fault extremely difficult.116 Such determinations would tax the staff and technology of even the FPC and could easily result in a court becoming bogged down in its fact-finding process.

In addition to the complexity of the gas industry itself, the extensiveness of the FPC's regulation of the industry further complicates the placement of fault on a pipeline for the creation of a shortage. The deep involveinent of the FPC in such areas as approving new sales, setting rates, and approving curtailment plans renders difficult the isolation of the pipeline company's fault in developing a situation requiring curtailment. Since the FPC must approve all new extensions of service through its certification procedure, ${ }^{117}$ the grant of a certificate in the face of an insufficient gas reserve makes the FPC to some extent an accomplice to the creation of a gas shortage. Although it might be argued that in some cases the fault lay solely with the pipeline connpanies in deceiving the Commission as to the extent of the available gas supply, in most cases the difficulty of isolating the effects of pipeline negligence from the effects of the FPC's regulation of the pipeline's actions severely diminishes the usefulness of fault as a factor for determining liability.

The FPC's role in establishing rates may also play a signficant part in determining the extent of future available reserves, in that

116. This burden is complicated by the uncertainty as to which forum is proper for each of the various questions involved. See notes 75-76 supra and accompanying text.

117. Natural Gas Act § 7, 15 U.S.C. § 717(f) (1970). 
the level of these rates may either encourage or discourage the investment by producers in exploration for new gas supplies. The recent adherence by the FPC to a concept of sanctity of contract in certain rate determinations ${ }^{118}$ is the direct result of FPC belief that its ratesetting procedure has a very real effect on the dedication of new gas to interstate sales. ${ }^{119}$ Since the relationship between rates and increased sales and exploration is no doubt intricate, it is clear that this rate-setting activity of the FPC does in fact complicate a determination of whether a shortage of gas was induced by the fault of the pipeline coinpany.

As a practical matter, the fact that the FPC had a part in approving pipeline actions may affect any decision by the FPC bearing on the question of the company's fault. While it is unclear what jurisdiction the FPC may have to decide sucli questions, ${ }^{120}$ when Commission-approved actions are later presented before the FPC as proof of fault by the curtailing pipeline, the FPC may be unwilling to find fault, either because the Commission initially approved the pipeline's action or because the Commission inay be reluctant to characterize an action approved by it as negligent.

FPC involvement may have a further effect upon determinations of liability since procedures established by the Commission to be followed by the pipelines in obtaining approval of proposed curtailment plans will perhaps determine whether the pipelines can invoke the defense of impossibility due to intervening government order. If Commission procedures require the pipelines to initiate the curtailment proceedings, the impossibility defense may be rendered unavailable because of the principle that the party who initially seeks a change in a regulation inay not be able to invoke the regulation to assert impossibility of performance. ${ }^{121}$ This fact was significant in recent litigation in which the court inplied that curtailment plans, if submitted on the initiative of the pipeline companies, inight receive less favorable treatment with respect to the company's liability than plans submitted in compliance with an FPC order. ${ }^{122}$

118. See note 24 supra and accompanying text.

119. See FPC Order No. 455, at 3-4. See also Placid Oil Co. v. FPC, Civil No. 71-2761 (5th Cir. Apr. 16, 1973).

120. See note 75 supra and accompanying text.

121. See note 56 supra and accompanying text.

122. See Atlanta Gas Light Co. v. Southern Natural Gas Co., 338 F. Supp. 1039 (N.D. Ga. 1972), aff'd in part, vacated and remanded in part, 476 F.2d 142 (5th Cir. 1973). This case, however, was concerned with only those plans for curtailment ordered by the FPC to be submitted for the Commission's approval. 
It is evident that complexities inherent in the gas industry make any attempt to prove that a pipeline company has been at fault in creating a gas shortage resulting in curtailment a difficult undertaking. In light of the uncertain potential for growth of the gas industry, the imponderables inherent in exploration efforts to find new reserves, and the intense involvement of the FPC in gas regulation, a court may be more likely to find fault in situations im which there is evidence of a deliberate over-commitment as opposed to a mere negligent mismanagement. Liability would, therefore, more likely result where there is proof either that new custoiners and sales were added with full awareness of a developing gas shortage, or that the pipelime had failed to disclose to the FPC known significant facts concerning the extent of its reserves in seeking certificates of convemience, perhaps in a bad faith effort to take advantage of possible immunity arising under an FPC curtailment order. Liability would be less likely where there is merely evidence of negligently madequate investment in exploration or of inaccurate calculation of cost. Thus, in recent cases, the allegations have focused on charges of deliberate wrongdoing rather than allegations of negligent mismanageinent. ${ }^{123}$

\section{Social Interests Affecting the Placement of LIABILIty}

Any discussion of the question of whether and under what circumstances a pipeline should be held liable for breach of contract resulting froin an FPC-ordered or approved curtailment must confront two final problems. First, would the imposition of liability in damages upon a pipeline when it breaches its contracts while obeying an FPC curtailinent order render the FPC unable to regulate the gas industry effectively? Second, who ought to bear the cost for the injury suffered by customers of pipeline companies who have been ordered by the FPC to curtail gas deliveries? ${ }^{124}$

Freedoin of a pipeline from liability in damages for breach of contract where the FPC has ordered curtailment may be essential to the FPC's ability to fulfill its mandate under the Natural Gas Act to as-

123. See Monsanto Co. v. FPC, 463 F.2d 799, 804 (D.C. Cir. 1972); United Gas Pipe Iine Co., No. 71-120, at 4 (F.P.C. Op. No. 606-A, Dec. 3, 1971); United Gas Pipe Linc Co., No. 71-120, at 22-23 (F.P.C., July 3, 1972) (presiding examiner's initial decision on remanded issues); Comment, supra note 107, at 1402.

124. It has even been stated by one writer that since the current liability question is largely one of first impression with no present common law or statutory guidelines, the courts will have the rare opportunity to "decide the question of damages solely on the basi' of policy considerations" (emphasis added). Comment, supra note 107, at 1403. 
sure adequate gas service under shortage conditions. ${ }^{125}$ If a pipeline could be held liable to its custoiners in damages for a curtailment pursuant to an FPC order, it might becoine necessary for the FPC to resort to a lawsuit to obtam compliance with its allocation. This would result in encumbered and inefficient proceedings, which might undermine compliance with FPC orders almost as much as if a court had ordered specific performance of the pipeline's original contract with its customer. ${ }^{126}$ Thus, the FPC has argued for pipeline immunity from liability in an analogous situation where pipeline companies are threatened with liability for damages from FPC-ordered curtailment under substitute fuel clauses: "The pipeline companies cannot be faced with the dilemma of providing nondiscriminatory service as ordered by the Commission and at the same time incur liability for breach of contracts which grant discriminatory preferences, directly or indirectly."

In addition to the dilemma which would be faced by compamies if they could be liable for breach of contract after FPC curtailment, it is possible that the FPC's rate-making authority would be undercut by the results of court-imposed liability, since, in order for the pipelines to bear the cost of the increased liability, it might be necessary for the Commission to increase gas rates. This result would amount to a courtimposed rate increase. On the other hand, if rates were not adjusted, heavy liability resulting from actions for breach of contract could make it more difficult for pipelines to afford future exploration, a consequence which would further aggravate the shortage and the FPC's ability to deal with it.

These problems seem to support the recognition under the Natural Gas Act of an FPC power to imsulate companies from contract liability for Commission-approved curtailments. The Commission's mandate to assure "just and reasonable" rates and service with no "undue preference or advantage" or "undue prejudice or disadvantage"128 to any party may be interpreted to incorporate such a power. There have been indications both in court decisions ${ }^{120}$ and in FPC opinions ${ }^{130}$ that the FPC has this power of immunization.

125. Natural Gas Act $\S \S 4-5,15$ U.S.C. § 717(c)-(d) (1970).

126. See note 76 supra and accompanying text.

127. United Gas Pipe Line Co., No. 71-120, at 3 (F.P.C. Op. No. 606-A, Dec. 3, 1971).

128. Natural Gas Act $\$ 4,15$ U.S.C. $\$ 717$ (c) (1970).

129. See, e.g., Michigan Consol. Gas Co. v. Panhandle E. Pipe Line Co., 226 F.2d 60 (6th Cir. 1955), cert. denied, 350 U.S. 987 (1956), where the court held that since the FPC order did not'specifically nullify the contractual obligation of the pipeline to reimburse its customer for losses incurred due to curtailment, the pipeline must be liable. 226 F.2d at 70 . The court thereby implied that the Commission has the 
Nevertheless, while a desire to assure effective FPC regulation may necessitate the adoption of a doctrine which insulates pipelines from liability, other considerations illuminate the difficulties inherent in such a policy. For example, a policy of insulation may result in an inequitable distribution of risk of loss due to curtailment among other parties. If a pipeline company is insulated from liability, the cost of this liability may be imposed on those parties who purchase and resell gas from the pipeline company in an intrastate market not regulated by the FPC. For example, if intrastate distributors, outside the jurisdiction of the FPC, were to be held liable for involuntary breach of contracts with their customers resulting from their FPC-induced inability to receive gas from the pipelines, it would seein to be inequitable to require them to bear the entire burden of liability without any recourse to receive some reimbursement from the interstate pipelines, whose similar involuntary breach of contract resulted in the intrastate distributor's loss. The resolution of this problem is uncertain, but the Act as well as court decisions recognize the necessity of, and provide for, close correlation and cooperation between the FPC and local agencies. This suggests that local agencies could similarly insulate the intrastate pipelines from liability. ${ }^{131}$ It would also appear that, if a state utility

power to nullify such contractual obligations of the pipelines. More recently in International Paper Co. v. FPC, 476 F.2d 121 (5th Cir. 1973), the Fifth Circuit, by holding that the adoption of a curtailment plan without more is not an absolnte defense, left open the possibility that it might have npheld an affirmative insulation by the FPC. In particular, the court remanded the case to the Commission to enable the FPC to support its statement that the substitute fuel clauses would result in "undue preference" and be against the "public interest." In stating that its views were probably not far removed from those of the FPC, id. at n.8, the court implied that it might very well uphold an affirmative insulation if such FPC action were factually supported in its order or opinion.

130. See United Gas Pipe Lime Co., No. 71-120, at 17 (F.P.C. Op. No. 606, Oct. 5, 1971), where the FPC stated that such a declaratory order would be unnecessary since implementation of the plan itself would be an absolute defense, thereby implying that it could when necessary affirmatively insulate the pipeline from liability.

Should the FPC lack the power to insulate, the next inquiry concerns what factual questions necessary to a determination of liability are within the exclusive jurisdiction of the Commission, thus providing it with the means to insulate indirectly. See note 77 supra and accompanying text. Although the development by the courts of the Commission's power to imsulate could make a statutory power of insulation nonessential, such power would still be desirable im that it would allow the utilization of the expertise of the Commission to determine under what circumstances a party should be held liable.

131. Section 17 of the Natural Gas Act, 15 U.S.C. $\$ 717$ (p) (1970), provides for cooperation between state and federal agencies. Further, the Court in Panhandle E. Pipe Line Co. v. Public Serv. Comm'n, 332 U.S. 507 (1947), recognized the joint jurisdiction of state and federal commissions to regulate direct sales to industrial customers within the state. 
commission refused to insulate intrastate distributors, the same contract defenses of impossibility available to pipeline companies would also be available to local distributors. ${ }^{132}$ In a real sense, performance of their contracts would also have become impossible due to a failure of continued existence of the subject matter as well as prevention by administrative order. To the extent that rate increases will be granted to coinpensate both the pipelines and the local distributors for their losses due to curtailment, these losses will necessarily be borne by the final customer. ${ }^{133}$ These and other considerations such as individual contractual provisions, propriety of a pipeline's allocation of curtailed deliveries, compliance with FPC curtailment orders, and fault of the pipeline in creating the shortage must be considered when determining whether pipelines will be held liable for breach of contract due to forced curtailment of gas deliveries.

\section{CONCLUSION}

There currently seems to be an unresolved conflict between the FPC and the Court of Appeals for the District of Columbia concerning whether or under what circumstances a gas supplier may be held liable to its customers for breacl of contract resulting from an FPC-approved curtailment. It is essential that these views be reconciled in order for the gas industry to make appropriate plans for dealing with present and future gas sliortages. The blame for the present lack of a definite resolution of the question of liability is not easy to fix. It is the result of the nebulous jurisdictional concepts concerning the proper relationship between the FPC and the courts, the transition in the change of outlook towards the gas industry due to the realization that gas reserves are decreasing, and the failure of the parties to litigate the matter fully. Thus, the views of the FPC and the courts have been expressed only in dicta.

It is likely, however, that the issue of pipeline liability will have to be confronted squarely in the near future. In the absence of contractual provisions to the contrary, it appears unlikely that a pipeline company would be held liable to its customers for implementation of an FPC-ordered curtailment plan arising from a gas shortage which was

132. See notes 54-59 supra and accompanying text.

133. The Fifth Circuit in International Paper Co. v. FPC, 476 F.2d 121 (5th Cir. 1973), recognized that if damages were to be paid from the pipeline's current revenues, such damages might result in the cost being passed on to the public in the form of rate increases. Judge Brown suggested that damages be imposed only if they can be assessed out of retained surpluses or assets not needed to meet customer demands. Id. 
not caused by any fault on the part of the pipeline. The application of this basic theory of liability is complicated due to the uncertain effect of three considerations: first, the extent to which private contractual provisions will be allowed to shift the risk of liability for curtailment from the pipelines' customers to the pipelines themselves; second, the extent to which FPC approval of a curtailment plan already placed into effect by a pipeline may insulate the pipeline from liability; third, whether fault of a pipeline company in causing a gas shortage will lead to liability and the circumstances under which such fault is likely to be found. This Note has attempted to clarify the role these factors will play in future litigation of pipeline liability for FPC-ordered gas curtailment. However, with the current gas shortage expected to continue into the future, the necessity of the formulation of a consistent policy concerning pipeline liability is clear. Until such a policy is articulated, these uncertainties will persist. 


\section{.}

